Bogusław Dunaj (1)

Państwowa Wyższa Szkoła Zawodowa w Tarnowie, Tarnów

boguslaw.dunaj@uj.edu.pl

\title{
ALEKSANDER ZAJDA (17 II 1937 - 24 V 2021) - UCZONY, DYDAKTYK, CZłOWIEK
}

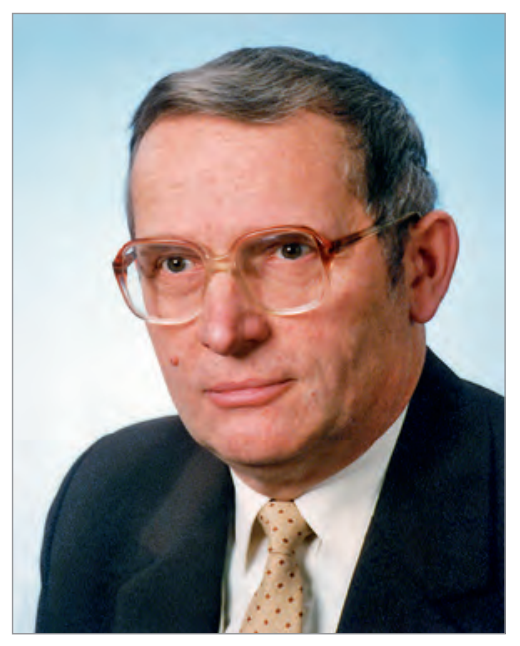

24 maja 2021 r. zmarł Profesor Aleksander Zajda, całe życie związany z Uniwersytetem Jagiellońskim. Spotkaliśmy się po raz pierwszy blisko 63 lata temu, na początku października 1958 r., gdy rozpoczynaliśmy studia na filologii polskiej. Znaleźliśmy się w gronie przeszło 120 osób przyjętych na pierwszy rok, przybyłych z różnych stron Polski. Wielu z nas spotykało się nie tylko na zajęciach w Gołębniku, ale też w Domu Studenckim „Żaczek”, gdzie mieszkała większość studentów spoza Krakowa. Olek Zajda był od nas kilka lat starszy, urodził się 17 lutego $1937 \mathrm{r}$. w Zebrzydowicach koło Kalwarii Zebrzydowskiej, w rodzinie rzemieślnika stolarza. Jego droga na studia polonistyczne nie była wcale prosta. Najpierw zdobył zawód praktyczny. Mianowicie po ukończeniu szkoły podstawowej w 1951 r. uczył się w dwuletniej stolarskiej szkole zawodowej w Kalwarii Zebrzydowskiej, a następnie przez pięć lat pracował jako stolarz. Nie poprzestał jednak na pracy w charakterze rzemieślnika, miał bowiem ambicje, by osiągnąć coś więcej. Dlatego też, nie przerywając pracy zawodowej, podjął naukę w I Liceum Korespondencyjnym dla Pracujących w Krakowie, które ukończył w $1958 \mathrm{r}$. W tym samym roku dostał się na polonistykę, co w owym czasie nie było bynajmniej łatwym zadaniem. Już od początku studiów dał 
kim prawniczemu, ale nie tylko, pisał bowiem również między innymi o zapożyczeniach w języku polskim, słownictwie rzemieślniczym, opracował nadto różne pola wyrazowe.

Profesor Zajda był wielkim miłośnikiem historii języka polskiego. Trzeba jednak podkreślić, że brał też udział w zainicjowanej przez Profesora Karasia zbiorowej pracy nad Słownikiem wymowy polskiej PWN (M. Karaś, M. Madejowa, Warszawa 1977). Jest autorem jednego z rozdziałów we wstępie: Problemy wymowy polskiej w ujęciu słownika. Niemało czasu poświęcił też na opracowanie Bibliografii dialektologii polskiej (red. J. Strutyński, Kraków 1981), której był współautorem.

Lata spędzone w uczelniach zagranicznych poświęcił nie tylko krzewieniu wiedzy o języku polskim, ale też opracowaniu podręczników do nauczania języka polskiego jako obcego: Mary i John Brown w Polsce (Kraków 1981) i Lekcje polonistyczne (Seul 1997).

Jako dydaktyk Profesor Zajda starał się propagować miłość do języka ojczystego, w szczególności do jego dziejów. Głęboka wiedza historycznojęzykowa sprawiała, że dla studentów stanowił wielki autorytet.

Profesor A. Zajda był człowiekiem skromnym. Nigdy nie dawał odczuć, że w niektórych obszarach wiedzy jest najlepszym znawcą danej problematyki. Nie okazywał też zawiści, a to w środowisku naukowym nie jest bynajmniej zjawiskiem powszechnym. Ujmowała również Jego życzliwość do ludzi. Mimo że od wielu lat był profesorem emerytowanym, uczestniczył bardzo często w zebraniach Katedry Historii Języka i Dialektologii, i to nie tylko jako uważny słuchacz, ale też niejednokrotnie jako referent. Będzie nam Go brakować zarówno jako uczonego, jak też jako mądrego, empatycznego człowieka. Dla piszącego te słowa bolesna jest świadomość odchodzenia pokolenia, z którym wspólnie dzieliliśmy trudy pracy naukowej, ale także przeżywaliśmy radości z naszych osiągnięć, spotkań, rozmów. 